\title{
TRANSFEKSI MERUPAKAN METODE TEKNOLOGI TRANSGENIK PENYISIPAN GREEN FLOURESCENT PROTEIN TERHADAP IKAN WILD BETTA
}

\author{
Eni Kusrini \\ Balai Penelitian dan Pengembangan Budidaya Ikan Hias \\ Jl. Perikanan No. 13 Pancoran Mas, Depok 16436, Jawa Barat \\ E-mail: ennyperikanan@yahoo.com
}

\begin{abstract}
ABSTRAK
Teknik transfer gen banyak dikembangkan untuk mengintroduksi molekul DNA ke dalam embrio. Keberhasilan transfer gen menggunakan metode transfeksi ditentukan oleh berbagai faktor, antara lain pemilihan larutan transfeksi yang sesuai dengan mempertimbangkan kesediaan secara komersial, mudah diaplikasikan, keberhasilan tinggi, dan tidak bersifat toksik terhadap embrio. Studi awal untuk mengetahui keberhasilan transfer gen terhadap embrio ikan wild betta digunakan Green Fluorescent Protein (GFP) dan juga dapat digunakan sebagai model terhadap ikan betta. GFP merupakan gen yang mengkodekan protein dan memiliki sifat berpendar hijau. Induk jantan dan betina dipijahkan dengan perbandingan 1:1 pada wadah baskom dengan ketinggian air $\pm 14 \mathrm{~cm}$ serta diberikan substrat. Transfeksi dilakukan pada embrio fase pembelahan 2 sel. Larutan transfeksi dibuat dari campuran DNA plasmid pada media $\mathrm{NaCl} 0.9 \%$ hingga mencapai konsentrasi akhir $100 \mu \mathrm{L}$ media (campuran transfast + DNA $+\mathrm{NaCl}$ ). Aktivitas gen ini dapat divisualisasikan dengan menggunakan sinar ultra violet. Keberhasilan dari teknik transfer gen tersebut dibuktikan dengan adanya ekspresi gen atau deteksi DNA gen GFP yang dimasukkan. Ekspresi hasil korporasi DNA ke dalam telur melalui transfeksi pada wild betta dan keberhasilan transfer gen GFP dapat dibuktikan dengan analisis PCR. Tujuan dari penulisan makalah ini adalah menguraikan tentang metode transfeksi yang efektif untuk teknologi transfer gen terhadap ikan wild betta.
\end{abstract}

KATA KUNCI: $\quad$ transfeksi, GFP, wild betta

ABSTRACT: Transfection of technology transgenic method for green fluorescent protein to wild Betta fish. By: Eni Kusrini

Gene transfer technique has been developed to introduce DNA molecules into the embryo. The success of gene transfer using transfection methods are determined by various factors, including the selection of the appropriate transfection solutions by considering the willingness of commercial, easy to apply, high efficacy, and is not toxic to the embryo. Preliminary studies to determine the success of gene transfer to wild betta fish embryos used GFP and can also be used as a model for betta fish. GFP is a protein and the gene that encodes green fluorescent properties. Male and female parent breed with a ratio of 1: 1 on the container basin with water height $\pm 14 \mathrm{~cm}$ and given substrate. Transfection is done on embryonic phase 2 cell division. Transfection solution made from a mixture of plasmid DNA in $0.9 \% \mathrm{NaCl}$ media to reach a final concentration of $100 \mathrm{uL}$ of media (mixed transfast $+\mathrm{DNA}+\mathrm{NaCl}$ ). The activity of this gene can be visualized using ultraviolet light. The success of gene transfer techniques is evidenced by the expression of genes or DNA detection of GFP gene is inserted. Expression of corporate results of DNA into the egg via transfection in the wild betta and the successful transfer of the GFP gene can be verified by PCR analysis. The purpose of this paper is describing the effective transfection method for gene transfer technology to wild betta fish.

KEYWORDS: $\quad$ transfection, GFP, wild betta

\section{PENDAHULUAN}

Transgenik adalah suatu produk bioteknologi melalui teknik rekayasa genetika. Pemindahan materi genetika (gen) dari suatu organisme untuk dikombinasikan ke dalam materi genetika organisme lainnya bertujuan agar gen yang dipindahkan akan diekspresikan oleh organisme yang menerima gen tersebut. Dengan kata lain, pada akhir proses akan dihasilkan suatu individu yang secara genetika telah berubah gennya karena membawa gen asing. Organisme inilah yang disebut organisme transgenik atau sering disebut pula genetically modified organisms (GMO).

Beberapa puluh pangan transgenik saat ini telah beredar di pasaran. Para pakar Ribosomal Deoksiribo 
Nucleic Acid (rDNA) telah mampu memotong atau mencopot suatu gen yang dikehendaki, dari individu hidup apa saja ke individuyang lain. Dibidang akuakultur, telah dilakukan beberapa metode transgenik antara lain penggunaan vektor yang dinamakan replication defective pantropic retroviral untuk menginfeksi sel lines ikan, kadal air, kodok, dan nyamuk. Metode alternatif lainnya adalah transfer gen dengan bantuan sel. Teknik ini merupakan pengembangan dari metode mikroinjeksi, dengan pertimbangan bahwa untuk menghasilkan ikan transgenik membutuhkan banyak waktu, biaya, fasilitas, dan tenaga. Teknik ini telah berhasil diaplikasikan pada ikan rainbow trout dengan menggunakan sel bakal gonad yang membawa Green Fluorescent Protein (GFP). Namun demikian teknik ini masih memerlukan penelitian lebih lanjut untuk dapat diaplikasikan pada spesies ikan lainnya (Alimuddin et al., 2003).

Transgenesis sangat bermanfaat dalam berbagai macam studi tentang biologi (Meng et al., 1999). Misalnya studi mengenai fungsi dan pola ekspresi dari gen serta untuk memproduksi produk komersial yang diinginkan (Kinoshita \& Ozato, 1995). Di bidang perikanan budidaya, transfer DNA eksogenous umumnya ditujukan untuk memproduksi galur transgenik yang mempunyai nilai komersial yang lebih tinggi (GarciaPozo et al., 1998). Perkembangan teknologi transgenik ikan di dunia meningkat dengan cepat. Keuntungan ekonomi yang potensial dari teknologi transgenik ikan ini tidak diragukan lagi. Ikan transgenik bisa juga digunakan sebagai bioreaktor untuk memproduksi bahan-bahan yang bersifat komersial maupun yang bermanfaat bagi kesehatan (Collas et al., 2000).

Teknik transfer gen banyak dikembangkan untuk mengintroduksi molekul DNA ke dalam embrio. Mikroinjeksi merupakan teknik transfer gen yang umum digunakan pada kegiatan transgenesis (Takagi et al., 1994; Alimuddin et al., 2003; Kato et al., 2007). Meskipun demikian, elektroporasi, mediasi lewat sperma, dan transfeksi juga memperlihatkan efektivitasnya tinggi dalam transfer DNA ke genom ikan (Khoo, 2000). Hasil penelitian yang dilakukan oleh Sun et al. (2005) yang mengkaji aplikasi metode transfer gen berbeda pada udang, yaitu mikroinjeksi, elektroporasi, dan transfeksi. Hasil penelitian menunjukkan bahwa metode transfeksi memberikan daya tetas yang paling tinggi, dengan jumlah telur yang diperlakukan dapat lebih banyak. Penelitian yang dilakukan oleh Parenrengi et al. (2011) transfeksi gen antivirus terhadap embrio udang windu tidak mempengaruhi daya tetasnya. Hal tersebut menunjukkan bahwa bahan transfeksi tidak bersifat toksik. Berdasarkan pertimbangan tersebut, metode transfer gen yang dipilih dalam penelitian ini adalah metode transfeksi mengingat ukuran telur ikan cupang $B$. imbellis yang relatif kecil. Dengan metode tersebut jumlah telur yang diaplikasikan relatif lebih banyak dalam satuan waktu tertentu (Sun et al., 2005).

Keberhasilan transfer gen menggunakan metode transfeksi ditentukan oleh berbagai faktor, antara lain pemilihan larutan transfeksi yang sesuai dengan mempertimbangkan kesediaan secara komersial, mudah diaplikasikan, keberhasilan tinggi, dan tidak bersifat toksik terhadap embrio. Namun demikian, umur embrio yang digunakan sama dengan metode transfer gen lainnya, transfeksi terhadap ikan wild betta dilakukan paling lambat fase 2 sel, pada ikan cupang $B$. imbellis adalah 4 menit. Sebagai studi awal untuk mengetahui transfer gen terhadap embrio ikan wild betta digunakan GFP dan juga dapat digunakan sebagai model terhadap ikan betta. Tujuan dari penulisan makalah ini adalah menguraikan tentang metode transfeksi yang efektif untuk teknologi transfer gen Green Flourescent Protein terhadap ikan wild betta.

\section{BAHAN DAN METODE}

Induk jantan dan betina dipijahkan dengan perbandingan 1:1 pada wadah baskom dengan ketinggian air $\pm 14 \mathrm{~cm}$ serta diberikan substrat (Gambar 1). Ikan jantan yang siap memijah akan membuat sarang busa di sekitar substrat. Umumnya fertilisasi terjadi 23 jam setelah pemasangan induk. Telur yang telah terfertilisasi dikoleksi dalam cawan petri kemudian dicuci dengan $\mathrm{NaCl}$ fisiologis $0.9 \%$ dan dilanjutkan dengan pencucian pada akuades.

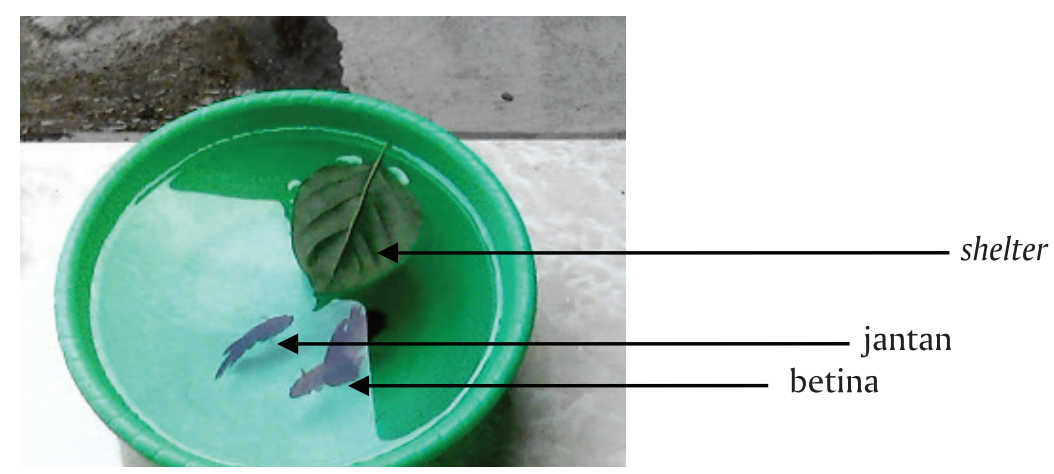

Gambar 1. Proses pemijahan ikan wild betta

Figure 1. Spawning process wild betta fish 


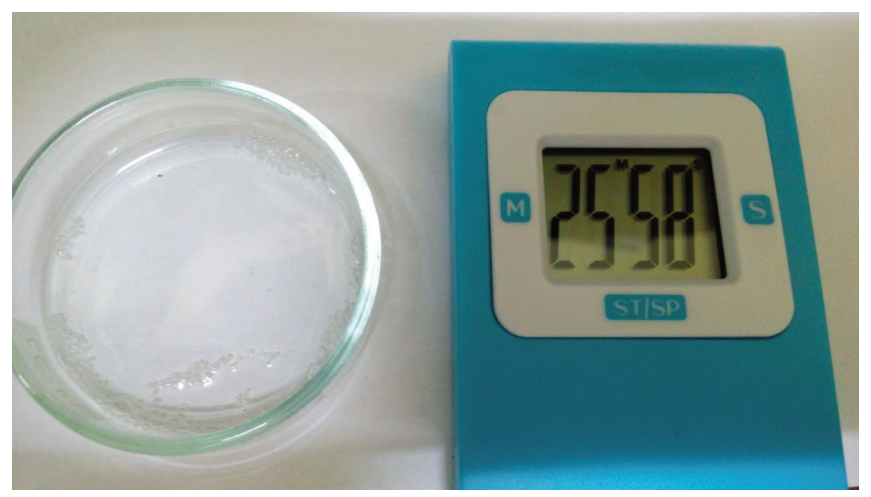

Gambar 2. Proses transfeksi selama 30 menit

Figure 2. Transfection process for 30 second

GFP yang diperoleh dari Prof. Dr. Yoshizaki (Tokyo Univ. Marine Sci. \& Technol.). Bakteri pembawa GFP akan dikultur dalam media cair yang mengandung Triptone $1,6 \%$, yeast extract $1 \%, \mathrm{NaCl} 0,5 \%$ dan antibiotik kanamisin, menggunakan shaker dengan kecepatan $250 \mathrm{rpm}$ pada suhu $37^{\circ} \mathrm{C}$, selama $16-18$ jam. Plasmid DNA akan diisolasi menggunakan kit EZ 10 Spin column Plasmid DNA sesuai dengan prosedur dalam manual. Konsentrasi DNA yang diperoleh akan dihitung menggunakan mesin DNA/RNA (Nano Drop 2000).

Transfeksi dapat menggunakan kalsium fosfat, liposom, dan transfast komersial. Larutan untuk transfeksi ikan wild betta digunakan transfast komersial X-tremeGENE HP DNA. Keberhasilan transfeksi ditentukan oleh konsentrasi transfektan dan konstruksi gen yang digunakan. Pemilihan larutan X-tremeGENE disesuaikan dengan ukuran dan tingkat pembelahan sel pada embrio ikan wild betta. X-tremeGene adalah larutan yang terdiri atas campuran lipid dan komponen lain yang berupa etanol $80 \%$, disaring dengan menggunakan membran berpori berukuran $0,2 \mu \mathrm{M}$ dan dikemas dalam botol kaca tanpa mengandung unsur dari manusia atau hewan.

Transfeksi dilakukan pada embrio fase pembelahan 2 sel. Larutan transfeksi dibuat dari campuran DNA plasmid pada media $\mathrm{NaCl} 0,9 \%$ hingga mencapai konsentrasi akhir $100 \mu \mathrm{L}$ media (campuran transfast + DNA + $\mathrm{NaCl}$ ). Campuran tersebut dimasukkan ke dalam tabung mikro $600 \mu \mathrm{L}$ diaduk dengan mikropipet dan dihomogenkan menggunakan vorteks sebelum diperlakukan. Selanjutnya larutan tersebut diambil menggunakan mikropipet dan dicampurkan ke embrio yang telah dikoleksi didalam cawan petri tersebut diaduk sampai semua terendam dan diinkubasi dalam suhu ruang selama 30 menit pada suhu ruang $\left(28^{\circ} \mathrm{C}-29^{\circ} \mathrm{C}\right)$ dapat dilihat pada Gambar 2. Telur diinkubasi dalam wadah berupa styrofoam berdiameter 10 inci dengan volume air $1 \mathrm{~L}$.

Keberhasilan dari teknik transfer gen tersebut dibuktikan dengan adanya ekspresi gen atau deteksi
DNA gen GFP yang dimasukkan. Ekspresi hasil korporasi DNA ke dalam telur melalui transfeksi pada wild betta dan keberhasilan transfer gen GFP dapat dibuktikan dengan analisis PCR.

\section{HASIL DAN BAHASAN}

Metode dalam transgenik di antaranya adalah mikroinjeksi, electroporation, sperm delivery, particle bombardment, dan lipofection. Namun metode yang umum digunakan adalah metode mikroinjeksi. Dengan metode ini, gen asing diintroduksikan ke dalam embrio ikan menggunakan sebuah jarum injeksi dengan diameter yang sangat kecil sekitar 5-7 $\mu \mathrm{m}$. Penggunaan mikroskop sangat diperlukan selama proses mikroinjeksi berlangsung.

Perkembangan metode transfer semakin mempertimbangkan analisis biaya, waktu, dan efisiensi yang lain. Adapun metode yang telah berkembang juga dan dapat diaplikasikan terhadap ikan adalah metode transfeksi. Metode ini tidak memerlukan alat yang spesifik, yaitu melalui perendaman embrio atau telur ikan. Metode ini sangat cocok untuk ikan-ikan maupun udang yang memijah secara alami. Berdasarkan hasil penelitian Sun et al. (2005) dengan melakukan tiga metode terhadap udang memberikan hasil terbaik pada metode transfeksi.

Teknik transfeksi dengan menggunakan reagen sebagai bahan transfeksi yang umumnya JetPEI, X-treme Gene, lipid, dan transfas. Larutan transfeksi yang dipilih sebaliknya tersedia luas secara komersial, mudah diaplikasikan, memiliki kemampuan delivery yang tinggi, dan tidak bersifat toksik terhadap embrio maupun pengguna.

Prinsip kerja dari transfer gen dengan metode transfeksi antara lain sebagai contoh sebuah plasmid dapat ditransfer dengan menggabungkan protoplas bakteri dengan sel yang akan ditransfeksikan. Penggabungan DNA secara in-vitro dengan berbagai molekul yang membentuk suatu kompleks yang memasuki sel bersifat efesien. Salah satu molekul yang biasa digunakan adalah kalsium klorida. Gugus fosfat 
DNA terikat ke kalsium menghasilkan suatu kompleks tidak larut, yang berpresipitasi jika kelebihan kalsium dan fosfat ditambahkan ke DNA. Campuran tersebut ditambahkan ke dalam medium kultur. Sejumlah kecil kompleks tidak larut yang melingkupi sel kemudian di endositosis secara spontan. DNA kemudian dilarutkan ulang di dalam sitoplasma sel. Sebagian besar DNA yang masuk didegradasi dan sisanya bisa mencapai nukleus, di mana DNA tersebut kemudian ditranskripsi.

Deteksi sementara pada hasil korporasi DNA ke dalam embrio melalui transfeksi ikan wild betta dapat dilihat pada Gambar 3. Pada Gambar 3 benih ikan wild betta berumur sekitar tiga bulan yang sudah dapat dilihat bahwa gen GFP yang disisipkan jelas terdeteksi positif. Untuk membuktikan dan memastikan keberadaan GFP (DNA) pada benih ikan wild betta tersebut dilakukan PCR terhadap sirip ekor yang diambil sekitar 0,45 g. Hasil dari PCR jaringan sirip menunjukkan semua positif membawa gen, tetapi harus dianalisis lebih lanjut untuk masing-masing individu.

Ekspresi gen sementara berhubungan erat dengan ketahanan dari DNA yang dimasukkan (Lyengar, et al., 1996). Tingginya ekspresi yang terjadi pada fase gastrula kemungkinan sebagai hasil dari akumulasi DNA yang diinjeksikan yang berlanjut pada peningkatan replikasi pada fase pembelahan (cleavage) dan akumulasi dari enzim (RNA polymerase II) yang menyebabkan dimulainya transkripsi pada saat MBT (mid-blastula transition). Lebih lanjut dijelaskan bahwa degradasi dari DNA pada saat fase lanjutan pada pembelahan sel diperkirakan akan menyebabkan penurunan bertahap dari jumlah DNA sehingga ekspresi sementara gen GFP akan semakin melemah.

Ekspresi sementara umumnya muncul setelah MBT, tergantung promoter yang digunakan. Pada penelitian ini, ekspresi sementara gen GFP pada larva mulai muncul pada saat tumbuhnya sirip. Sebenarnya pada fase gastrula sudah mulai muncul tetapi waktu itu tidak diamati, karena kekhawatiran ikan mengalami stres. Akhirnya pengamatan secara deskriptif dilakukan bertahap mulai umur tiga minggu sampai sirip sudah mulai panjang dan kemungkinan dapat dipotong untuk dilakukan PCR.

Keberhasilan masuknya gen yang ditransfeksi dapat dianalisis dengan sintesis cDNA embrio maupun benih. Untuk selanjutnya apabila ingin mengetahui gen GFPyang ditransfeksikan diturunkan atau tidak dapat dilakukan dengan verifikasi tehadap gonad calon induk ikan wild betta (F0). Apabila dalam gonad ternyata terekspresi gen tersebut, maka ikan wild betta hasil transfeksi nantinya akan disilangkan dengan ikan yang tidak diberi perlakuan dan sebaliknya. Hal tersebut dilakukan dengan maksud untuk mendapatkan F1, apakah ekspresi gen GFP yang diijeksikan dapat diwariskan, dan seberapa persen nilai pewarisannya, serta ekspresi tersebut terdapat pada jaringan apa. Perlakuan tersebut berlangsung seterusnya F2, F3, dan seterusnya, dengan demikian hasil penelitian ini merupakan penelitian dasar yang baru dapat melihat ekspresi gen pada benih ikan wild betta.

Keuntungan secara ekonomi dari rekayasa genetika ini sangat menjanjikan dibandingkan dengan teknik pemijahan selektif, waktu yang dibutuhkan sangat singkat untuk mencapai hasil yang sama. Sehingga tujuan dari transgenik adalah untuk mendapatkan sifat yang diinginkan dan peningkatan produksi. Meskipun teknologi transgenik ini memungkinkan untuk diaplikasikan dalam bidang akuakultur (budidaya perikanan), namun masih perlu dilakukan penelaahan khusus untuk mengetahui teknologi tersebut.

Teknologi manipulasi gen untuk meningkatkan laju pertumbuhan ikan potensial untuk diaplikasikan dalam industri akuakultur. Dengan perbaikan teknik

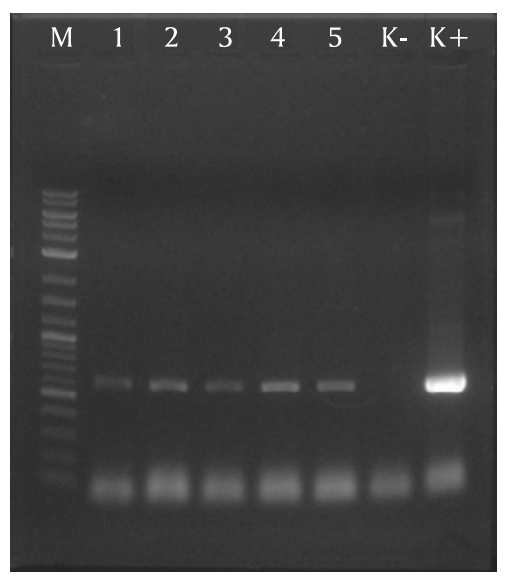

Gambar 3. Deteksi DNA gen GFP yang ditransfeksi pada embrio ikan wild betta $(\mathrm{M}=$ Marker; $1,2,3,4,5=$ sampel uji; $\mathrm{K}-=$ Kontrol negatif; $\mathrm{K}+=$ Kontrol positif)

Figure 3. Detection of gene GFP DNA by transfected to wild betta fish embrio $(M=$ Marker; $1,2,3,4,5=$ sample; $K=$ Control negative; $K+=$ Control positive) 
dan penambahan pengalaman dalam metode insersi gen, telah diproduksi berbagai spesies ikan yang pertumbuhannya cepat. Keberhasilan penerapan teknologi transgenik ini bergantung kepada transfer gen yang diekspresikan dan diwariskan dengan cara yang stabil serta dapat diprediksi. Sedangkan untuk metode transfeksi dapat berpotensi dikembangkan dalam transgenesis terhadap ikan wild betta karena reagen yang digunakan dalam penelitian ini tidak bersifat toksik pada individu target (Prasetio et al., 2013).

\section{KESIMPULAN}

Metode penyisipan (induksi) gen pemendar warna (GFP) dapat dilakukan menggunakan metode transfeksi pada embrio ikan wild betta.

Gen pemendar warna (GFP) yang diinsersikan ke dalam telur telah diidentifikasi pada embrio secara massal dengan PCR

\section{DAFTAR ACUAN}

Alimuddin, Yoshizaki, G., Carman, O., \& Sumantadinata, K. (2003). Aplikasi transfer gen dalam akuakultur. Jurnal Akuakultur Indonesia, 2(1), 41-50.

Collas, P., Husebeye, H., \& Alestrom, P. (2000). Transferring foreign genes into zebrafish eggs by microinjection. Transgenic Animal: Generation and Use, p. 119-122.
Garcia-Pozo, S., Bejar, J., Shaw, M., \& Alvarez, M.C. (1998). Effect of exogenous DNA microinjection on early development response of the seabream Sparus aurata. Molecular Marine Biology and Biotechnology, 7(4), 248-257.

Kato, K., Takagi, M., Tamaru, Y., Akiyama, S., Konishi, T., Murata, O., \& Kumai, H. (2007). Construction of an expression vector containing a ß-actin promoter region for gene transfer by microinjection in red sea bream Pagrus major. Fisheries Science, 73, 440-445.

Khoo, H.W. (2000). Transgenesis and its applications in aquaculture. Asian Fish Sci., 8, 1-25.

Kinoshita, M., \& Ozato, K. (1995). Cytoplasmic microinjention of DNA into fertilized medaka (Oryzias latipes) eggs. The Fish Biology Journal Medaka, 7, 59-64.

Kobayashi, S.I., Alimuddin, Morita, T., Miwa, M., Lu, J., Endo, M., Takeuci, T., \& Yoshikazi, G. (2007). Transgenic nile tilapia (Oreochromis niloticus) over-expressing growth hormone show reduced ammonia excretion. Aquaculture, 270, 427-435.

Meng, A., Jessen, J.R., \& Lin, S. (1999). Transgenesis: methods in cell biology. In Detrich, H.W. III, Westerfield, M., \& Zon, L.I. (Eds.). 60, 133-148.

Parenrengi, A., Tenriulo, A., Tonnek, S., \& Lante, S. (2011). Transfer gen antivirus pada embrio udang windu, Penaeus monodon dalam berbagi konsentrasi DNA. J. Ris. Akuakultur, VI(93), 353-361. 
